\title{
Organic geochemical characteristics of Jurassic petroleum system in Abadan Plain and north Dezful zones of the Zagros basin, southwest Iran
}

\author{
Mehdi Kobraei* ${ }^{\circ}$, Jalil Sadouni and Ahmad Reza Rabbani \\ Faculty of Petroleum Engineering, AmirKabir University of Technology, Tehran, Iran. \\ *Corresponding author. e-mail: mehdi.kobraei@gmail.com
}

MS received 7 March 2018; revised 19 June 2018; accepted 23 June 2018; published online 25 February 2019

Jurassic succession has resulted in prolific oil and gas reservoirs in southwest Iran. In order to geochemically investigate the Jurassic petroleum system and assess the source rock of these hydrocarbons, 32 source rock samples (from well cutting and surface section) and 4 condensate samples were analysed using geochemical approaches. Rock-Eval pyrolysis and vitrinite reflectance measurement were done on rock samples. Then, condensate samples and source rock extracts were subjected to gas chromatography, gas chromatography-mass spectrometry and isotopic analyses in order to establish oil-oil and oil-source rock correlation. The hydrocarbon generation prediction was then confirmed by petroleum system modelling. The results indicated that the middle Jurassic Sargelu Formation with average total organic carbon (TOC) and hydrogen index values of $3.8 \%$ and $600 \mathrm{mg} \mathrm{HC} / \mathrm{g}$ TOC, respectively, can be classified as good to excellent source rock with kerogen of type II. The maturity indicators revealed late oil to wet gas generation window for the Jurassic Sargelu Formation. Biomarker parameters showed marine carbonate source rock with advanced level of thermal maturity for the source rock of the condensates. Furthermore, there were good correlations between Jurassic Sargelu Formation and the studied oil and condensate samples which proved the Sargelu Formation as the main source rock of the Jurassic petroleum system in the study area. The basin modelling results also confirmed late oil to wet gas window maturity for the Sargelu Formation enabling it as a source rock for generating gas condensate accumulation in southwest Iran. The hydrocarbon generation from Sargelu Formation began in the late Cretaceous and its peak expulsion occurred in the Miocene time.

Keywords. Source rock; Jurassic reservoir; condensate; Abadan Plain; Iran.

\section{Introduction}

Most of Iran's explored oil and gas is believed to have been sourced from Jurassic (Sargelu Formation) and Cretaceous (Garau and Kazhdumi formations) intervals and trapped in Cretaceous and Cenozoic reservoirs in the Dezful Embayment and Abadan Plain area.
The Middle Jurassic succession includes very significant source rocks over southwest of Iran through eastern Iraq in the Zagros basin owing to the high total organic carbon (TOC) content of the Sargelu Formation that was deposited throughout the Jurassic basin in these areas (Jassim and Goff 2006). There is no published paper on geochemical characteristics of Jurassic petroleum system in 
southwest of Iran while several studies document the stratigraphy and sedimentology of Jurassic strata (Sadooni 1997; Alsharhan and Nairn 2003; Sherkati and Letouzey 2004; Rabbani and Kamali 2005; Alizadeh et al. 2007).

Pitman et al. (2004) reported that Jurassic Sargelu Formation exhibits good to excellent petroleum generation potential and the kerogen prevalent in the formation is of type II-S. The thermal modelling conducted by the researchers indicated that in most parts encompassed by the Abadan Plain and Iraqi parts of Zagros basin, the formation has reached and passed the oil generation window (Pitman et al. 2004; Zeinalzadeh et al. 2015).

In the southwest of Iran a few wells have penetrated Jurassic succession and proved the occurrence of hydrocarbon as condensate to wet gas. Due to deep burial of Jurassic sediments in the Zagros basin and difficulty of access to samples, there are limitations to geochemical study of source rock and hydrocarbon generation, migration and entrapment in the Jurassic petroleum system.

The aim of this study was to address the characteristics of middle Jurassic source rocks in the study area (figure 1). To characterise the quantity, quality and maturity of organic matter in the studied formation, Rock-Eval pyrolysis and vitrinite reflectance measurements were carried out, and a one-dimensional (1D) burial history was created and evaluated to derive additional information on source rock maturity stages and hydrocarbon generation in southwest Iran. Also, the present study presents a detailed geochemical description of hydrocarbon discovered in the Jurassic reservoir in the region. The first step was to characterise geochemical parameters in the Jurassic condensate. Then, the biomarker composition in the studied samples was classified and finally, using oil-oil and oil-source correlation, the oil family and respective source rocks were identified.

This study integrated detailed analytical work on outcrop, well cuttings and oil (condensates) samples to explain the above-mentioned issues. In addition, thermal modelling was done in the key localities to assess the maturity level and timing of hydrocarbon generation in the source rock. In this regard, PetroMod 1D software has been undertaken for two representative well locations.

\section{Geological background}

In the Late Permian-Early Triassic, the southern Tethys Ocean bordered the Arabian platform in the northeast. This marine environment existed between the time of opening of the Tethys and the collision of the Arabian Plate with the Eurasian margin (including the Iran block) in the Early Miocene (Stocklin 1968; Berberian and King 1981). As a result of this collision, the northern margin of the Arabian Platform was subducted northward beneath Eurasia and extensively folded and thrusted in the present Zagros region, particularly during the Styrian orogenic phase in Middle Miocene and Atikan phase in Late MiocenePliocene time. In addition to Palaeogene orogenic folding and thrusting, some regional structural features in the region persisted from the beginning of the Middle Jurassic until the Early Miocene (Sepehr and Cosgrove 2004).

Wide, shallow intracratonic seas or basins covered the eastern and northeastern parts of the Arabian Platform during most of its geological history (Muris 1980). As a result of relative sea level changes, the basin shore fluctuated widely and underwent a low-amplitude differential subsidence. This is confirmed by seismic observations of meandering channel systems in the upper part of the Sarvak Formation. Sedimentation consisted predominantly of calcareous deposition that was temporarily interrupted either by evaporite deposition or by clastic influxes (Stöcklin 1974). High TOC source rocks were developed when the environment became anoxic because of a combination of sea level rise or increasing subsidence, a humid climate and the occurrence of upwelling currents in the Tethys Ocean (Bordenave and Huc 1995). The main reservoirs in southwest of Iran occur in the Asmari Formation (Fars Group) and Bangestan, Khami and Deh Ram Groups of the Zagros Foredeep, as shown in figure 2.

The Zagros basin is divided into three zones: the Zagros Thrust Zone (ZTZ), which forms the eastern margin; the Imbricated Zone, which is about $80 \mathrm{~km}$ wide and lies to the west of the ZTZ; and the Folded Belt, which is farther west and in which the intensity of folding decreases towards the southwest (Ala 1974).

Development of the Zagros basin started in the Late Cretaceous as a result of foredeep subsidence that preceded the continental closure along the Zagros suture. The area previously had been a stable shelf margin of the Afro-Arabian continental plate (Muris 1980).

In the permo-Triassic episode, the Zagros basin was divided into two main basins. In the northwestern part the Lurestan and the Fars basin to 


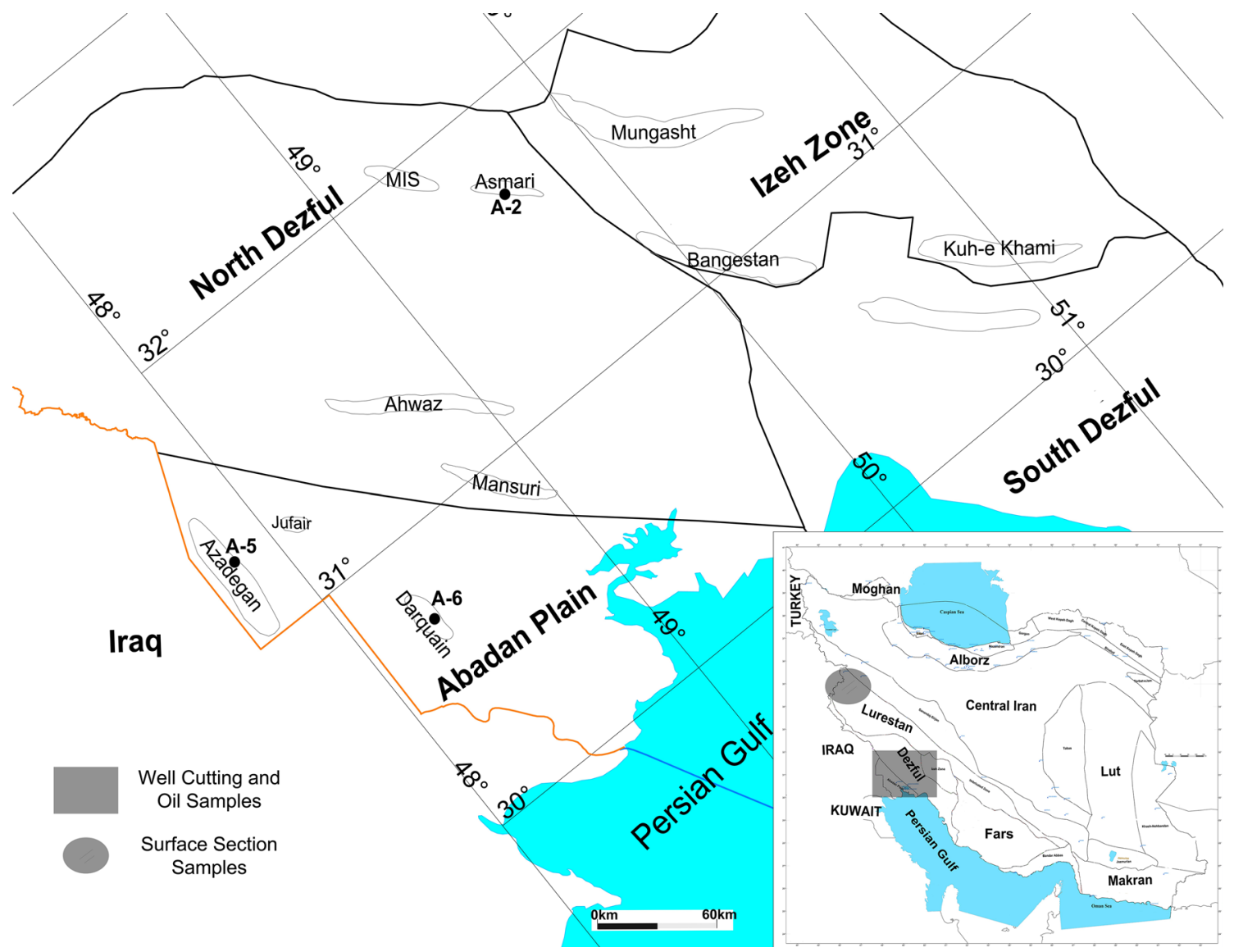

Figure 1. Location map of the studied area and oil fields in the Zagros basin with main tectonic boundaries (modified after NIOCEXP 2010; Zeinalzadeh et al. 2015).

the southeast in which sedimentary successions are quite different (Setudehnia 1978). The JurassicCretaceous in the Lurestan and northwestern part of the Dezful Embayment contain deeper water sediments (Sepehr and Cosgrove 2004).

Middle Jurassic sediments in the Zagros basin are represented by contrasting facies in the study area (figure 2). In the west, basinal organic-rich carbonate source rock facies of the Sargelu Formation were deposited in a deep basin which has been proven in deep wells in MIS-306 and Bangestan-1. In the eastern parts, time equivalent platform carbonates of the Surmeh Formation were deposited as can be seen at outcrop on the Mungasht and Khami anticlines (see figure 1 for location). Facies relationships between the basinal Jurassic source rocks (Sargelu Formation) and its time equivalent dolomitised carbonate platform have not yet been observed due to lack of outcrop and well control.

The Dezful Embayment is a tectonic feature in the southwestern edge of the Zagros basin. The embayment contains Iran's major oil fields; it is the centre of the southwestern Iranian oil province, which geologically belongs to the northern part of the Arabian plate. The name 'Dezful Embayment' was assigned to that part of the Zagros basin where there is no evidence of the Asmari Formation (Oligo-Miocene) in outcrop (Motiei 1995). The Dezful Embayment is bound by three main tectonic elements. There is an E-W trending flexure zone (Balaroud fault) and a 'mountain front' flexure with a NW-SE trend in the northern part. To the east and southeast the Dezful Embayment is bound by a complex zone of faults and flexures having an N-S trend (Kazeroun-Qatar fault). The structural and stratigraphic features of the Dezful Embayment have been well documented since the middle of the last century (Falcon 1967; Motiei 1995; Alavi 2007).

The Abadan Plain is a structural unit located in southwest of Iran. The boundaries of this plain include the Zagros Fold Belt in the northeast and the Persian Gulf in the south (figure 1). The generally $\mathrm{N}-\mathrm{S}$ trending anticlines 




Figure 2. Stratigraphic chart of the studied area in southwest Iran. The main sources are indicated by two stars and the marginal ones by one star (after Bordenave and Hegre 2010).

of the Abadan Plain are not exposed in outcrop but occur in the subsurface. The most important structures in this area contain oil, including the Juffair, Darquin, Azadegan and Hendijan oil fields.

Geologically, the Abadan Plain is the continuation of the northeastern part of the Arabian plate and as such the main structural trends correspond to those of Kuwait, southern Iraq, the northern Persian Gulf and northeastern Saudi Arabia.

\section{Materials and methods}

Only a few wells in southwest of Iran have reached Jurassic petroleum system in which four condensate samples (taken during drill stem test) 


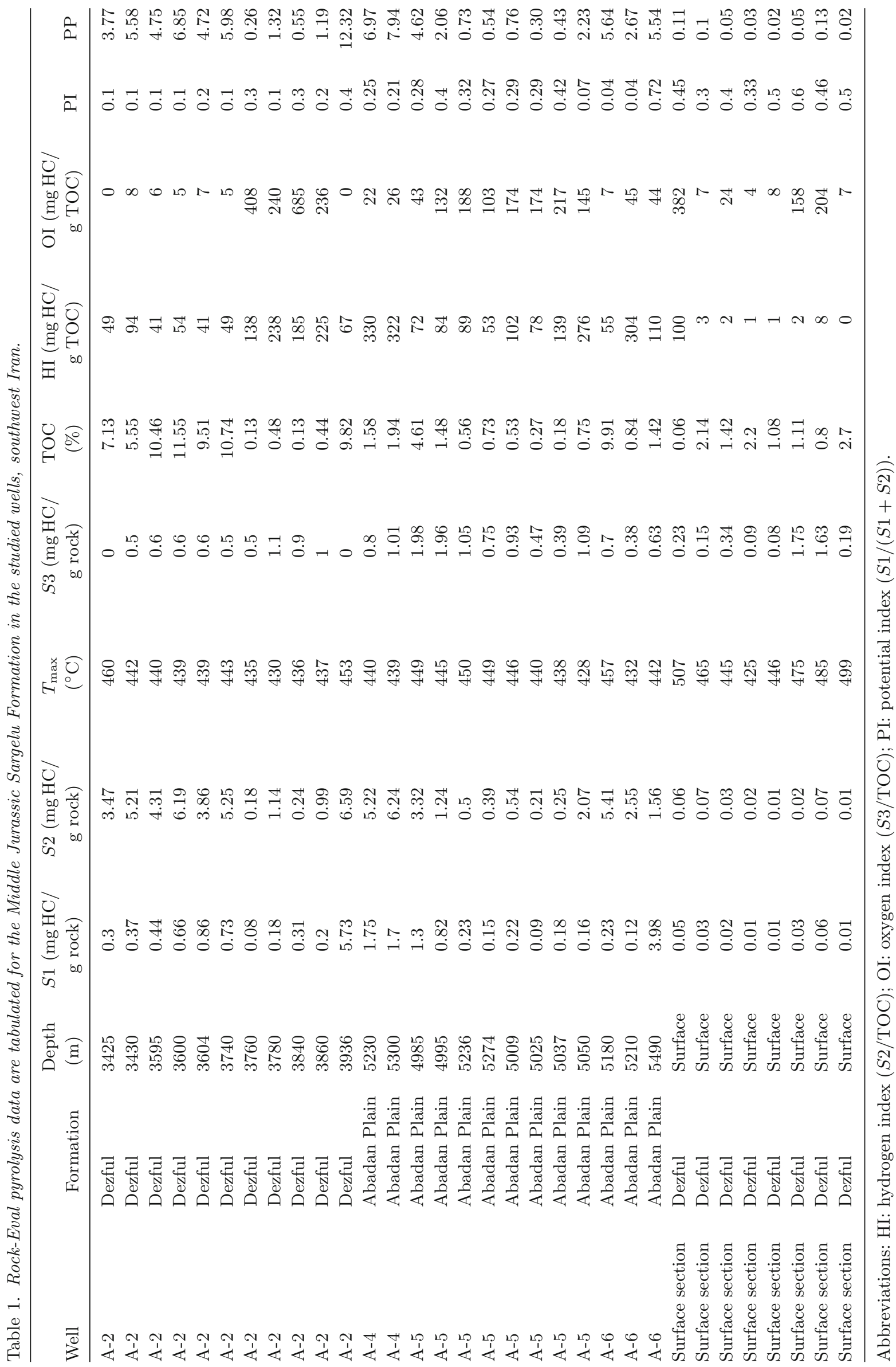


were collected for this study. In addition, 24 cutting samples were collected from four oil wells in different fields in southern part of the Dezful Embayment and Abadan Plain align with eight samples from two surface sections in the Lurestan area to characterise source potential of Jurassic Sargelu Formation (see figure 1 for localities). The samples were selected on the basis of their lithology and dark colour and correlated with Gamma Ray log, which may point to high organic matter content.

\subsection{Source rock geochemistry}

To evaluate generation potential and thermal maturity of organic matter in different source rocks, the most widely used method is Rock-Eval pyrolysis (Espitalié et al. 1977). After decontaminating the samples from mud additives (such as mica and iron filings) using a binocular microscope, in order to have a uniform and comparable size of sediments for geochemical analysis, they were ground to $<180 \mu \mathrm{m}$.

Pyrolysis analyses have been done using a Rock-Eval 6 apparatus manufactured by Vinci Technologies (Tissot and Welte 1978). Rock-Eval analysis results show several geochemical parameters including $S 1, S 2, S 3$, TOC and $T_{\max }$ (table 1 ). Some additional calculated parameters from measurements such as HI (hydrogen index), OI (oxygen index) and PI (production index) also are listed. After preliminary experiments, four rock samples were selected for complementary analyses which are explained in the following.

Nine samples have been selected for measuring vitrinite reflectance considering results of RockEval pyrolysis. Reflectance was measured using a Zeiss Axipolan II microscope in oil immersion following the method described by Taylor et al. (1998)

Table 2. Vitrinite reflectance measurement results of studied samples.

\begin{tabular}{lccccc}
\hline Well & Depth $(\mathrm{m})$ & Mean $(\%)$ & Min $(\%)$ & Max $(\%)$ & No. of measures \\
\hline A-2 & 3720 & 0.9 & 0.79 & 0.95 & 27 \\
& 3735 & 0.86 & 0.81 & 0.9 & 23 \\
\multirow{2}{*}{ A-5 } & 3750 & 0.92 & 0.8 & 1 & 38 \\
& 5036 & 0.75 & 0.73 & 0.95 & 12 \\
\multicolumn{2}{l}{ Surface section } & 0.73 & 0.71 & 0.89 & 21 \\
Surface section & 0.83 & 0.76 & 0.79 & 33 \\
Surface section & 1 & 0.75 & 0.86 & 32 \\
\hline
\end{tabular}

Hydrocarbon Potential

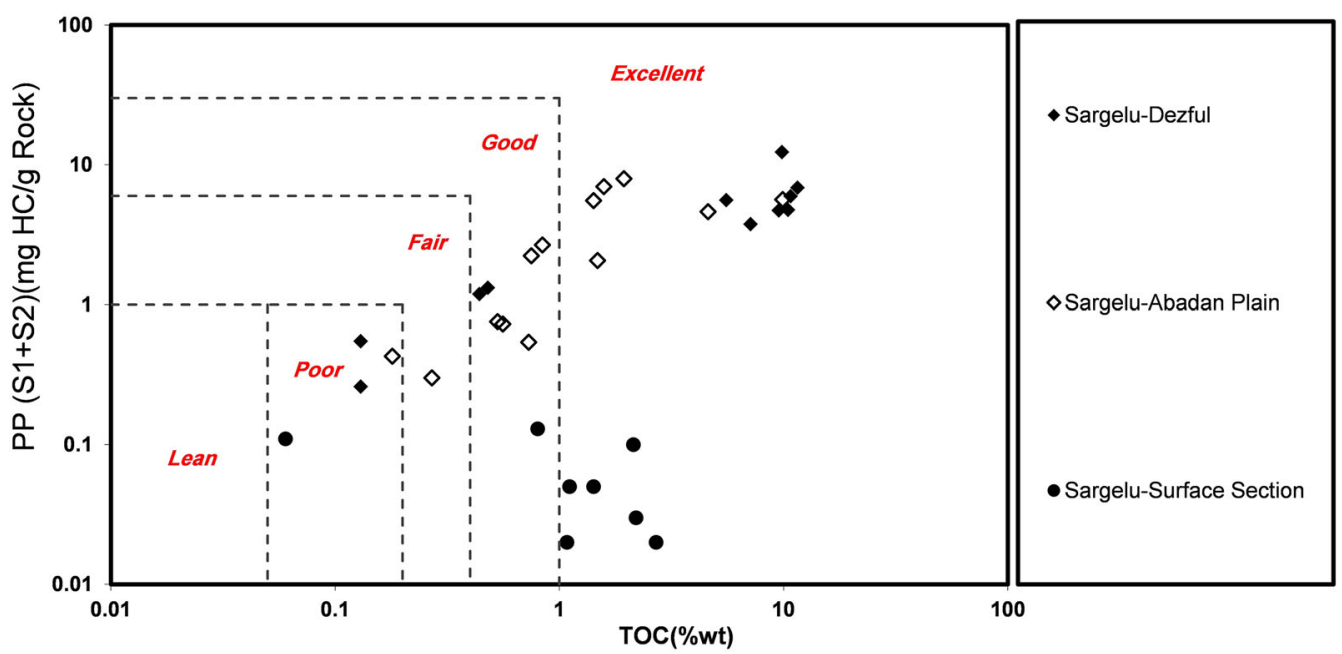

Figure 3. Plot of PP vs. TOC showing good to excellent source potential of Sargelu Formation (Peters and Cassa 1994). 
and Alizadeh et al. (2012). The results can be seen in table 2.

Regarding the Rock-Eval pyrolysis results, four rock samples were selected for extraction and other complementary analyses which are explained in the next section. The organic matter extraction was done by Soxhlet using dichloromethane (DCM) overnight and then the solvent was removed by centrifuge evaporator. To fractionate the extract, a liquid column of silica gel activated by alumina was employed.

\subsection{Oil geochemistry}

In this study, oil (condensate) samples from two wells were subjected to preliminary experiments such as oil gravity, API (American Petroleum
Institute) measurements, asphaltene precipitation and column chromatography. Column separation is basically a system which will separate the extracted material into saturated hydrocarbons, aromatic hydrocarbons and resins. Asphaltenes can either be separated from the extract before separation or they remain a part of the resin fraction. The asphaltene fraction was precipitated by the addition of $n$-hexane. The remaining fractions were then separated into saturate, aromatic and resins by column chromatography, using alumina/silica gel (2/1 ratio) columns. These fractions were eluted with $n$-hexane, benzene and methanol, respectively. Then complementary stages such as gas chromatography (GC), GC-mass spectrometry (GC-MS) and stable isotope analysis were performed.
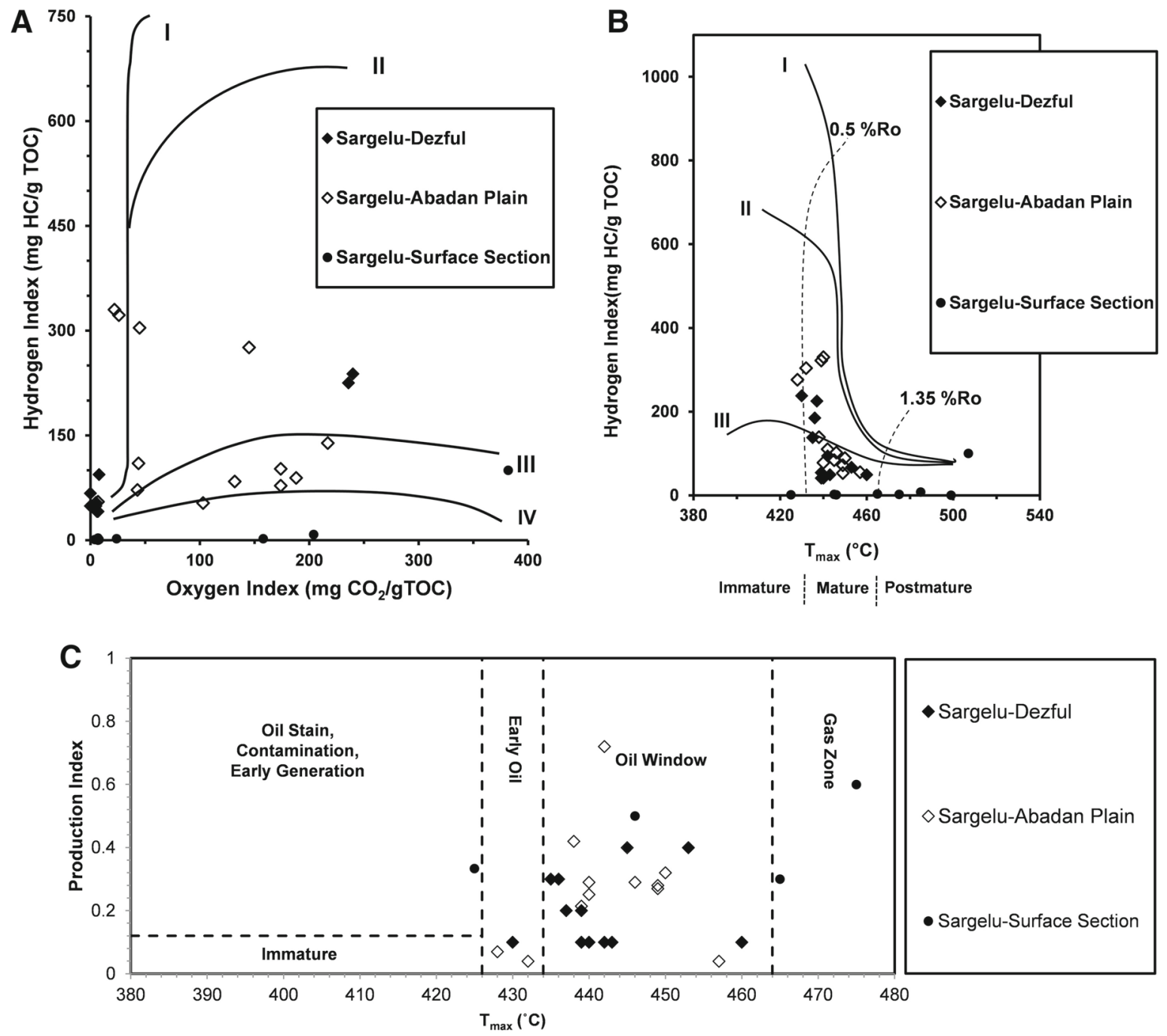

Figure 4. Plots of HI vs. OI detecting kerogen type (A) and $T_{\max }$ yielding maturity of source rock (B) and plot of PI vs. $T_{\max }$ yielding maturity of source rock (C) (Hunt 1996). 
After fractioning the oil samples, saturates and aromatic fractions were analysed on a gas chromatograph. GC apparatus which has been used in this study is of type 'chrompakcp9000' equipped with Flame Ionization Detector (FID) and capillary column of type 'CP-Sil-5' with $30 \mathrm{~m}$ length and $0.25 \mathrm{~mm}$ inner diameter and coupled to a Finnigan MAT GCQ ion trap mass spectrometer. Oven's initial temperature was $70^{\circ} \mathrm{C}$ and was programmed to increase at the rate of $4^{\circ} \mathrm{C} / \mathrm{min}$ to $300^{\circ} \mathrm{C}$. Carrier gas was helium and compressed air and hydrogen were used as the flame of the detector. The sample was injected in split-less mode while the injector temperature was set at $275^{\circ} \mathrm{C}$. For processing data a Finnigan system was used. Relative percentages and absolute concentrations of different compound families of saturates and aromatics such as normal alkane, pristane, phytane, terpanes, steranes and DBT (dibenzothiophenes) were detected and related parameters were calculated.

Oil and rock extracts contain components whose ${ }^{13} \mathrm{C}$ isotopic composition is related to the origin of the organic matter and thermal history as well as any post-accumulation changes such as biodegradation or migration. These data are used in geochemical assessments for source rock evaluation and correlation. The analysis of their composition is made by stable carbon isotope mass spectrometry, using a VG Sira10 Mass Spectrometer. This method describes the measurement of the relative amounts of ${ }^{13} \mathrm{C}$ to ${ }^{12} \mathrm{C}$ of oil and sediment extracts.

The measurement is made relative to an international standard, PDB (a belemnite from the Upper Cretaceous Peedee Formation, USA) via a secondary standard NBS22 (a lube oil).

For stable carbon isotopic analysis (i) sediment samples must have their inorganic carbon (carbonate) removed and (ii) oil and sediment extracts must have the volatile material (below $n-\mathrm{C}_{10}$ ) removed, as variable evaporation of this material will cause data scatter.

\section{Results and discussion}

\subsection{Source rock geochemistry}

The quantity of organic matter in a rock sample usually is expressed as TOC (Hunt 1996). In the

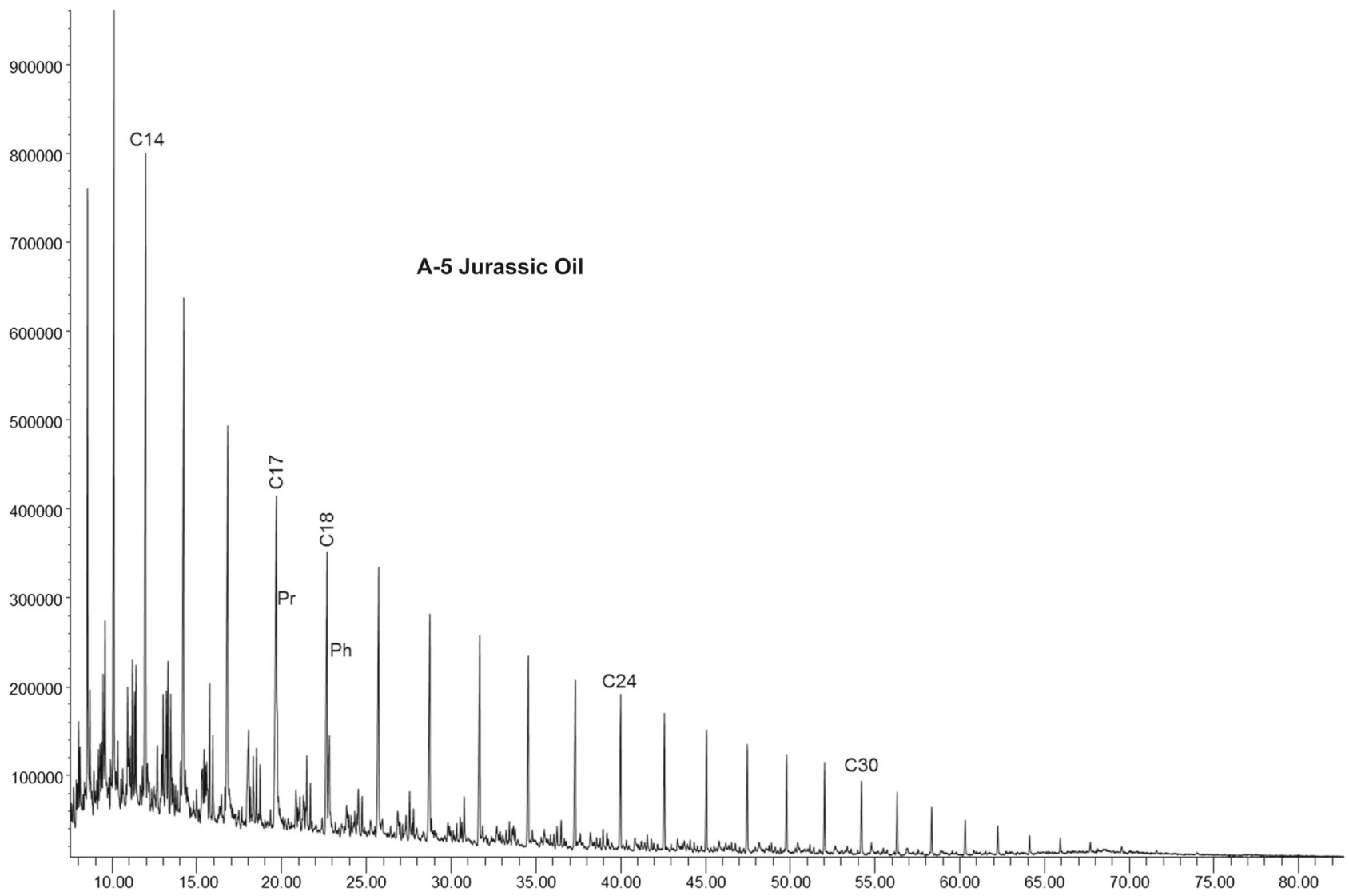

Figure 5. GC-SAT chromatogram of the A-5 Jurassic oil-1 sample indicating $n$-alkanes as well as Pr and Ph. 
Sargelu Formation, TOC content is variable and changes from $0.13 \%$ up to $11.55 \%$ in the cutting samples. Average TOC in well cutting samples is about $3.8 \%$ while in the samples from surface sections, TOC values are much lower and average TOC is $1.4 \%$ (table 1). According to Peters and Cassa (1994), TOC values of Sargelu Formation are consistent with very good source rocks. The highest TOC values can be seen in the northern part of Dezful embayment in the range of $7-11 \mathrm{wt} \%$.

In some other studies on the Sargelu Formation in Zagros basin (Pitman et al. 2004), it has been shown that the TOC is variable from $2 \%$ to more than $6 \%$ in well cutting and less than $2 \%$ in the surface section. Hence, it appears that variability in organic matter content in the Sargelu Formation is a regional phenomenon and a result of basin sedimentary environmental conditions.

Other important pyrolysis provided parameters are $S 2$ and HI which are the remaining hydrocarbon potential or amount of hydrocarbon obtained by heating during pyrolysis (Hunt 1996). S2 yield of Sargelu Formation changes from 0.2 to more than $6.59 \mathrm{mg} \mathrm{HC} / \mathrm{g}$ rock in the well samples and is less than $0.07 \mathrm{mg} \mathrm{HC} / \mathrm{g}$ rock in the surface sections. The present HI value of Sargelu Formation in the studied area is quite variable and ranges between 40 and more than $330 \mathrm{mg} \mathrm{HC} / \mathrm{g}$ TOC. Initial HI value of this Formation is calculated as $620 \mathrm{mgHC} / \mathrm{g}$ TOC in a joint study between NIOC (National Iranian Oil Company) and BP (British Petroleum; NIOC 2003, unpublished report). In another basin modelling study in the Mesopotamian basin in Iraq, the initial HI value for Sargelu and Naokelekan Formations was considered as $600 \mathrm{mgHC} / \mathrm{g}$ TOC (Pitman et al. 2004).

$T_{\max }$ is a temperature at which there is a maximum in $S 2$ curve during pyrolysis. The level of thermal maturity for different types of organic matter may be estimated from the $T_{\max }$ data. In this study, average $T_{\max }$ values in well samples is about $445^{\circ} \mathrm{C}$ (without considering samples which have unusually low or high $T_{\max }$ ) and in the surface section average $T_{\max }$ is $468^{\circ} \mathrm{C}$ which shows late oil to wet gas generation window (Hunt 1996).

Plot of production potential (PP) vs. TOC in figure 3 shows good to excellent source potential of Sargelu Formation in all the studied areas. TOC and PP measurement can be influenced by contamination in samples. $S 1 /$ TOC ratio for most of studied samples is lower than one which shows there was no contamination (such as

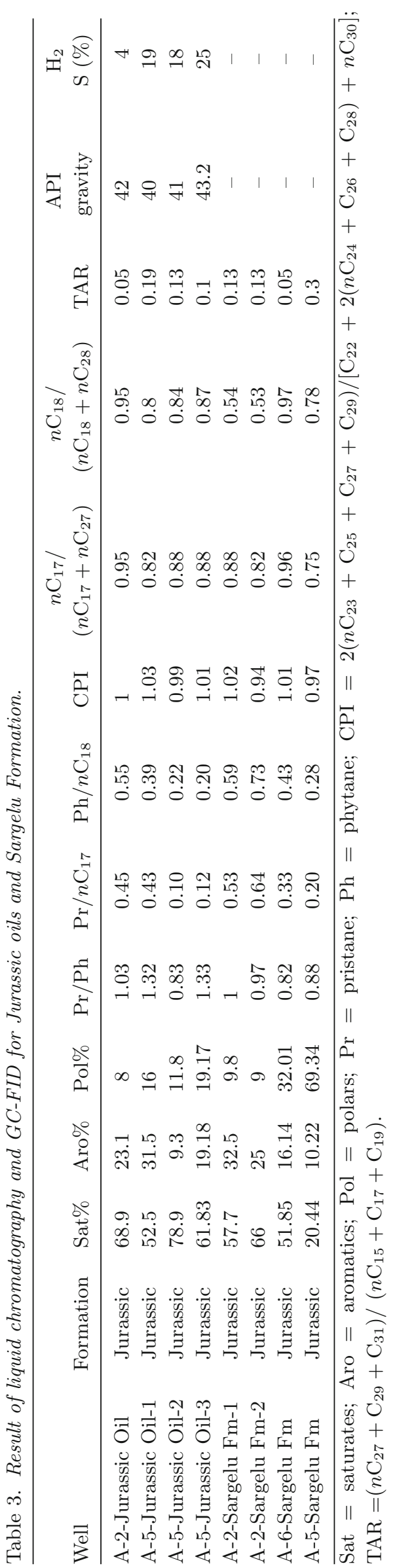



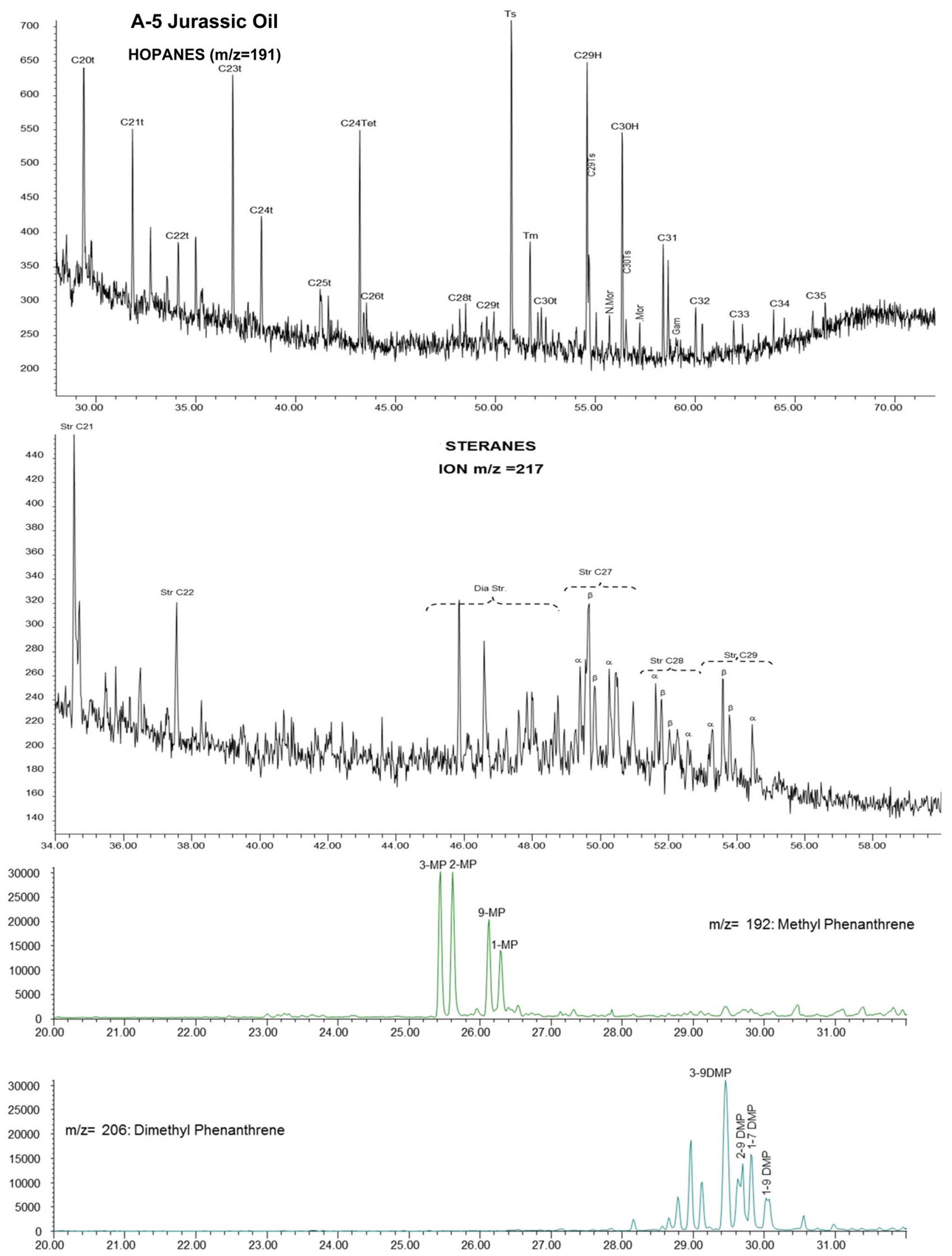

Figure 6. Typical saturate GC-MS fragmentograms of the A-5 Jurassic oil-1 sample. 
drilling mud, migrated hydrocarbons, etc.) in the studied samples and all organic matter are indigenous (table 1).

Maximum hydrocarbon which can be produced by a specific source rock is turned to SPI (source potential index) if no expulsion occurred (Demaison and Huizinga 1991). In the Sargelu Formation considering there has been expulsion, remaining SPI can be calculated as follows:

$$
\mathrm{SPI}_{r}=h \times[(S 1+S 2) / 1000] \times \rho,
$$

where $h$ is the thickness of source rock in metre, $S 1$ and $S 2$ are in $\mathrm{mg} \mathrm{HC} / \mathrm{g}$ rock or $\mathrm{kg} \mathrm{HC} / \mathrm{t}$ rock and $\rho$ is the source rock density in $\mathrm{t} / \mathrm{m}^{3}$. The average thickness of Sargelu Formation in the studied area is about $170 \mathrm{~m}$, the average remaining production potential $(\mathrm{PP}=S 1+S 2)$ is $3.66 \mathrm{mg} \mathrm{HC} / \mathrm{g}$ rock and density of Sargelu Formation is considered as $2.68 \mathrm{t} / \mathrm{m}^{3}$ based on mixed limestone and shale lithology. Remaining SPI of Sargelu Formation is about $1.6 \mathrm{t} \mathrm{HC} / \mathrm{m}^{2}$ which classifies it as high potential source rock. It should be considered that initial potential of this formation had been much higher.

Determining the type of kerogen in Sargelu Formation, HI is plotted vs. OI in figure 4(A) (Hunt 1996). Regarding this plot, kerogen of Sargelu Formation can therefore be classified as type II or II/III. As it was mentioned, initial hydrogen index had been much higher and therefore in HI vs. OI plot, moving to higher hydrogen index, the kerogen type will be type II.

Source rock maturity was assessed on the basis of Rock-Eval $T_{\max }$ and PI values. $T_{\max }$ for Sargelu Formation in the studied area varies between 426 and $460^{\circ} \mathrm{C}$ and the average is $442^{\circ} \mathrm{C}$ which indicates thermal maturity in the oil window. Plots of $\mathrm{HI}$ and PI vs. $T_{\max }$ also show oil window level of maturity in the kerogen (figure 4).

Another important and reliable parameter for indicating maturity is vitrinite reflectance measurement. Vitrinite reflectance in the studied samples ranges between $0.75 \%$ and $1 \%$ with average of $0.85 \%$ which indicates oil window maturity in the source rock (table 2).

\subsection{Oil geochemistry and correlation}

In this study, four oil (condensate) samples from Jurassic reservoir (Sargelu and Neyriz formations) of two fields (Asmari and Azadegan) in the Zagros basin were analysed. The oils have API gravity in the range of 40-43 and amount of $\mathrm{H}_{2} \mathrm{~S}$ gas in the oil samples ranges between $4 \%$ and $27 \%$ which place them in the light and sour oil classification. Shortchain $n$-alkanes predominance can be detected in the oil (figure 5), carbon preference index is close to 1 and pristane/phytane ratio ranges $0.8-1.3$ for all oil samples (table 3 ).

Regarding gas chromatograms envelope and lack of 25-norhopane in the GC-MS fragmentograms (Peters and Moldowan 1993), there is no evidence of alteration process such as biodegradation in the studied oil (figure 6).

Indicating thermal maturity of oil samples a set of biomarker and diagrams can be used according to different references. Very low values of $\mathrm{Pr} / \mathrm{C}_{17}$ and $\mathrm{Ph} / n \mathrm{C}_{18}(0.1-0.45)$ in the plot of figure 7, CPI (carbon preference index) close to unity and high values of $\mathrm{C}_{29} \alpha \alpha S /(S+R)$ and $\beta \beta /(\beta \beta+\alpha \alpha)$ ethylcholestane ratios (table 4$)$ show

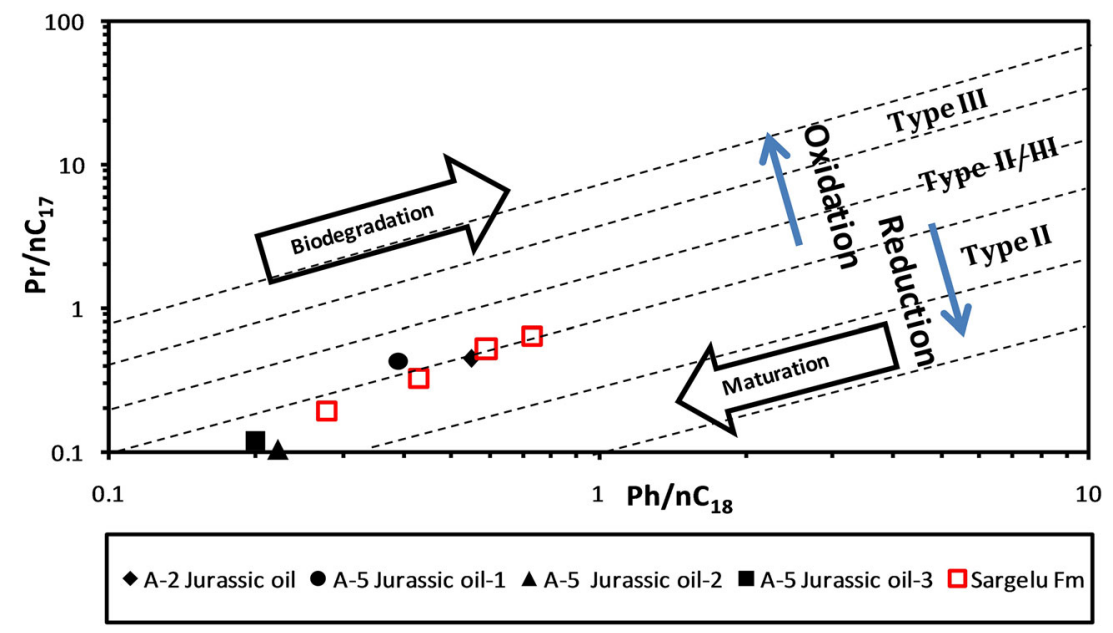

Figure 7. Plot of $\mathrm{Pr} / n-\mathrm{C}_{17}$ vs. $\mathrm{Ph} / n-\mathrm{C}_{18}$ ratios for Jurassic oil and source rocks in southwest of Iran (after Hunt 1996). 
advanced maturity of Jurassic oil and cutting samples. Aromatic biomarkers which are more resistive to thermal cracking, also show high maturity for studied oil and source rock samples, as it is shown in figure 8, and using methylphenanthrene index (MPI)-1 index, amount of vitrinite reflectance is calculated for oil samples between $0.7 \%$ and $1.1 \%$ (Radke and Welte 1983). There is an acceptable correlation between studied oil and Jurassic source samples in the mentioned figures.

Geochemical biomarkers can be used to investigate the nature and depositional environment of suspected source rock of the oil. In the studied oil samples, higher predominance of low chain $n$-alkanes align with $\mathrm{Pr} / n-\mathrm{C}_{17}$ and $\mathrm{Phy} / n-\mathrm{C}_{18}$ (figure 5) indicates marine organic matter (Peters and Moldowan 1993). Plot of $\mathrm{C}_{27}-\mathrm{C}_{28}-\mathrm{C}_{29}$ sterane relative distribution shows low amount of $\mathrm{C}_{29}$ steranes which indicate little contribution of higher plants. As it is shown in ternary diagram of figure 9 , in most studied samples there is a shifting towards $\mathrm{C}_{27}$ indicating marine carbonate source rock (Moldowan et al. 1985). In addition, ratio of $\mathrm{C}_{29}-\mathrm{C}_{30}$ hopane and higher values of $17 \alpha(\mathrm{H})$ trisnorhopane $(\mathrm{Tm})$ relative to $18 \alpha(\mathrm{H})$ trisnorhopane $(\mathrm{Ts})$ indicate marine carbonate source for the studied samples (Peters and Moldowan 1993).

Using statistical processing on the isotope analysis results, a parameter called canonical variable (CV) can be calculated (Sofer 1984). CV value lower than -2 in table 5 indicates no contribution of lacustrine and paralic shale while all of studied oil originate from marine carbonate and shale environment. According to plot of figure 9, there is good correlation in the studied oil and Jurassic source rock samples.

In addition to geochemical biomarker for source rock environment, DBT/Phen ratio is dependent on environment of source rock. In the studied samples, DBT/Phen ratio changes between 1.5 and 4.5 which confirms marine environment of source rock.

Peters et al. (1999) used biomarker ratio oleanane /(oleanane + hopane) for recognition of oil younger than Cretaceous, and for all studied oil this ratio is zero which means Cretaceous and older sources. Plot of $\mathrm{Pr} / \mathrm{Ph}$ ratio vs. ${ }^{13} \delta \mathrm{C}$ saturates in figure 10 shows source age of studied samples; early Mesozoic age has been derived for the studied oil samples (Chung et al. 1992). Bjorøy et al. (1992) believed that with advance increase in maturity

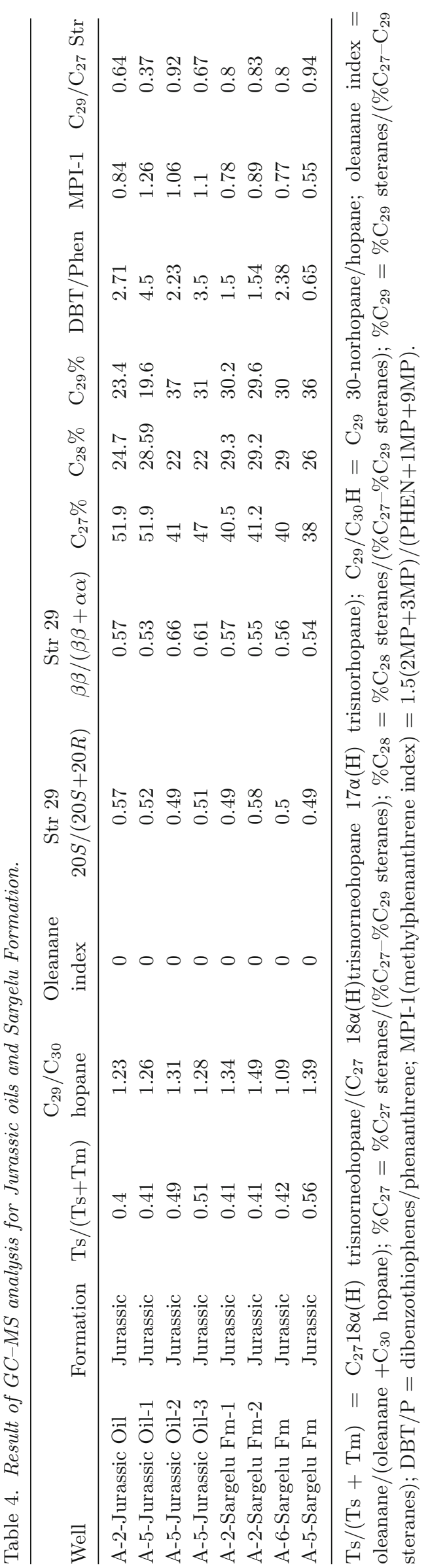




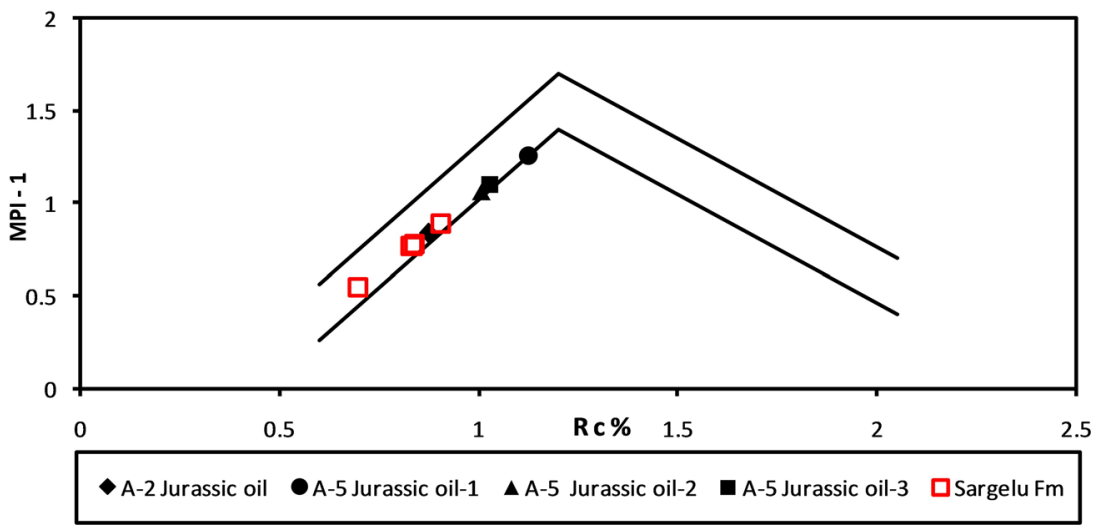

Figure 8. Plot of MPI-1 vs. calculated vitrinite reflectance for studied oil and source rock samples (Radke and Welte 1983).

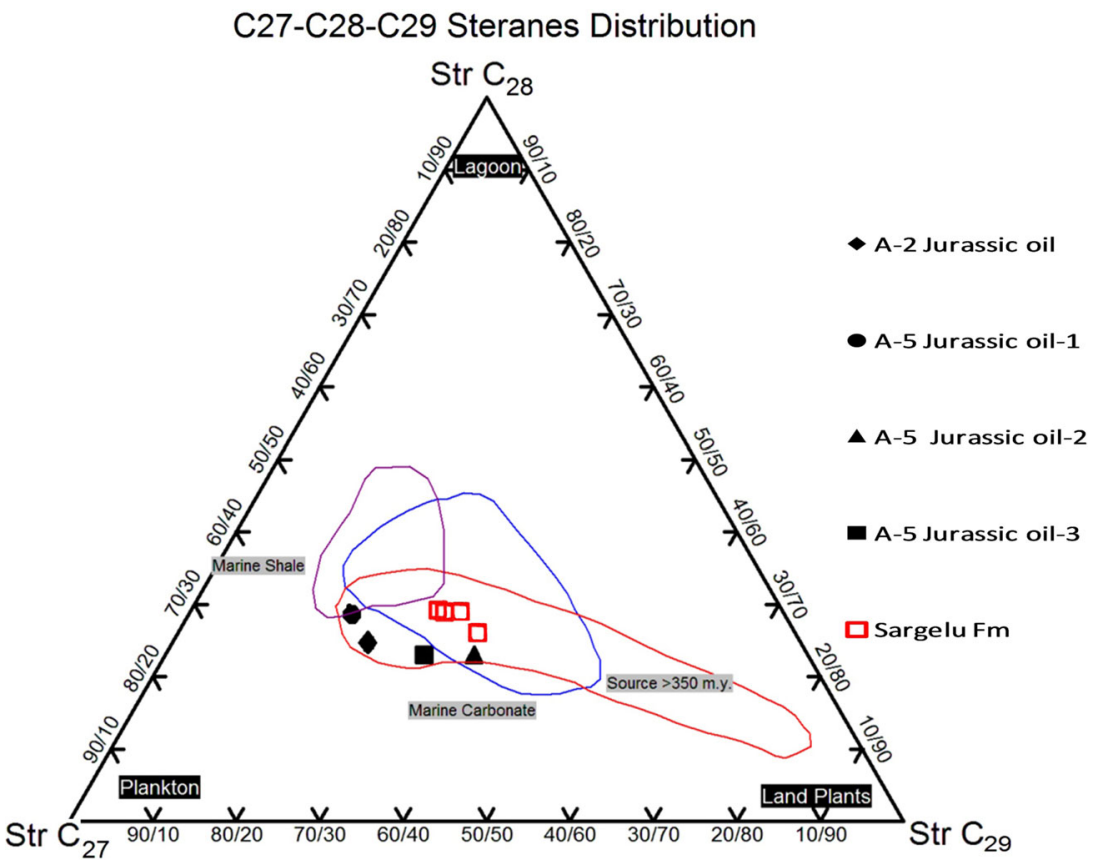

Figure 9. Ternary diagram of $\mathrm{C}_{27}-\mathrm{C}_{28}-\mathrm{C}_{29}$ steranes for studied oil and rock samples (after Moldowan et al. 1985).

Table 5. Result of isotope analysis in the studied samples.

\begin{tabular}{lcccc}
\hline & & Saturated HC & Aromatic HC & \\
\cline { 2 - 4 } Well & Formation & $\delta^{13} \mathrm{C}(\mathrm{PDB})$ & $\delta^{13} \mathrm{C}(\mathrm{PDB})$ & CV \\
\hline A-2-Jurassic Oil & Jurassic & -26.6 & -25.7 & -2.691 \\
A-5-Jurassic Oil-1 & Jurassic & -27.2 & -26.8 & -3.67 \\
A-5-Jurassic Oil-2 & Jurassic & -27.6 & -27.1 & -3.339 \\
A-5-Jurassic Oil-3 & Jurassic & -27.8 & -27.2 & -3.06 \\
A-2-Sargelu Fm-1 & Jurassic & -27.1 & -27 & -4.377 \\
A-2-Sargelu Fm-2 & Jurassic & -29.1 & -27.8 & -1.133 \\
A-6-Sargelu Fm & Jurassic & -25.6 & -24.3 & -2.043 \\
A-5-Sargelu Fm & Jurassic & -27.3 & -26.8 & -3.417 \\
\hline CV $=$ canonical variable $=-2.53 \delta^{13} \mathrm{C}$ saturates $+2.27 \delta^{13} \mathrm{C}$ aromatics -11.6.
\end{tabular}

of oil samples, the isotope values (especially in lighter fractions) will be heavier (more positive). As mentioned in the previous paragraphs, biomarker parameters show high maturity in the studied samples. Regarding these comments, in the plot of figure 10, the isotope values of saturate should be 


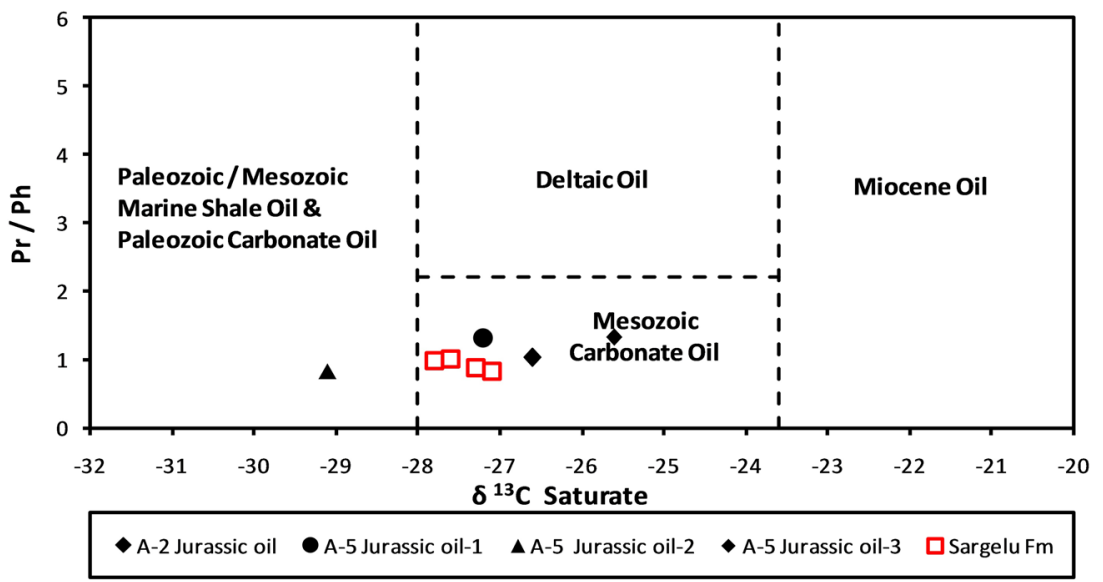

Figure 10. Plot of $\mathrm{Pr} / \mathrm{Ph}$ vs. $\delta^{13} \mathrm{C}$ saturate indicating source rock age (Chung et al. 1992).
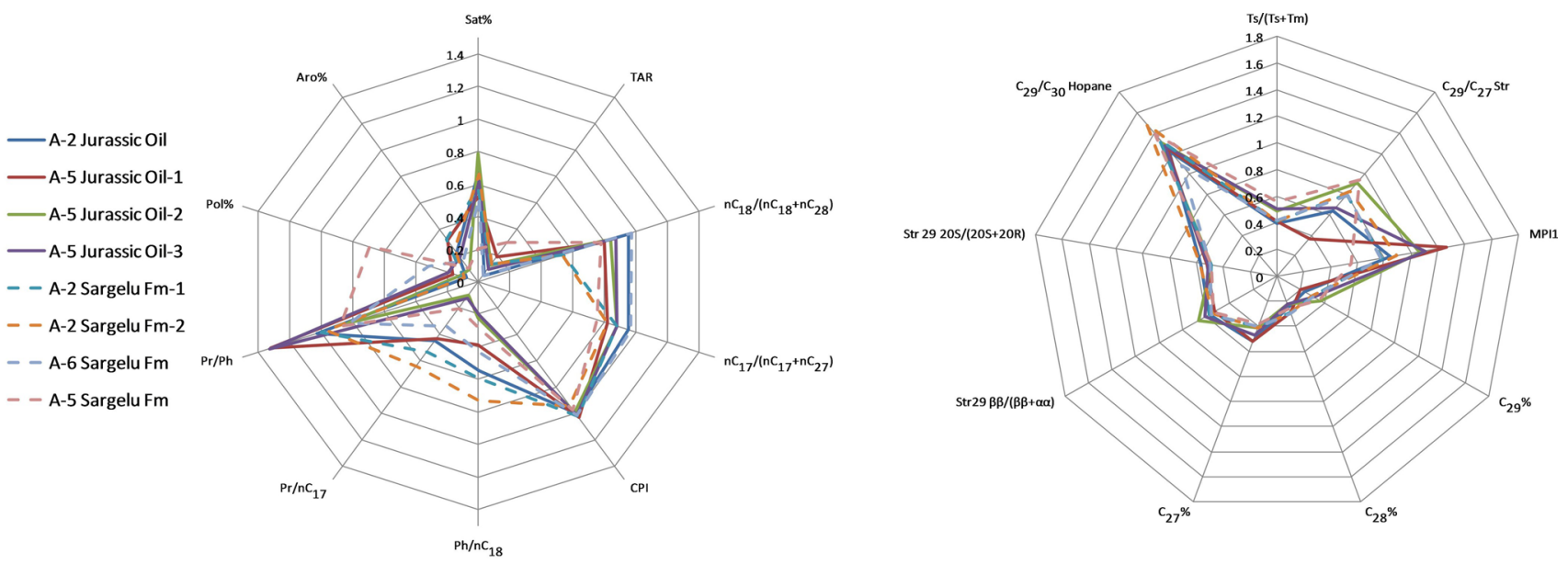

Figure 11. Plot of star diagrams using GC and GC-MS parameters for oil-oil and oil-source correlation.
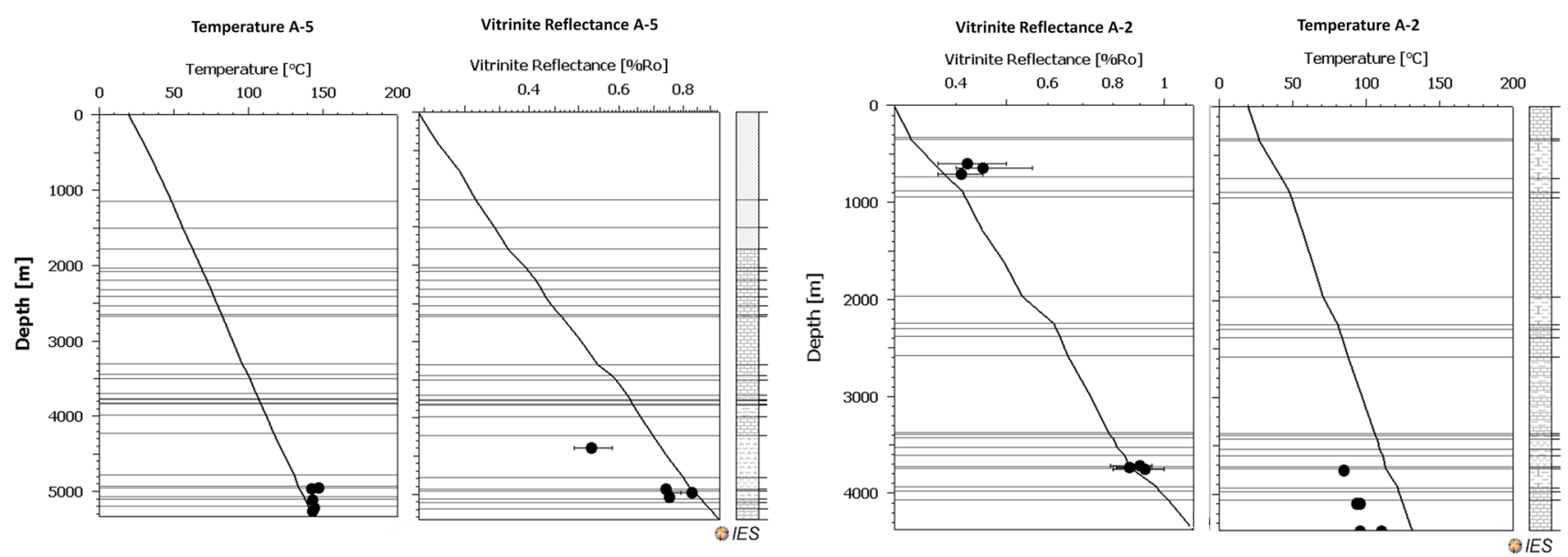

Figure 12. Plot of correlation between calculated and measured parameters in studied oil field.

shifted more leftward in which there will be good correlation between Jurassic condensate and source rock samples.
All GC and GC-MS parameters have been used in order to do oil-oil and oil-source rock correlation in the studied Jurassic petroleum system. As it 


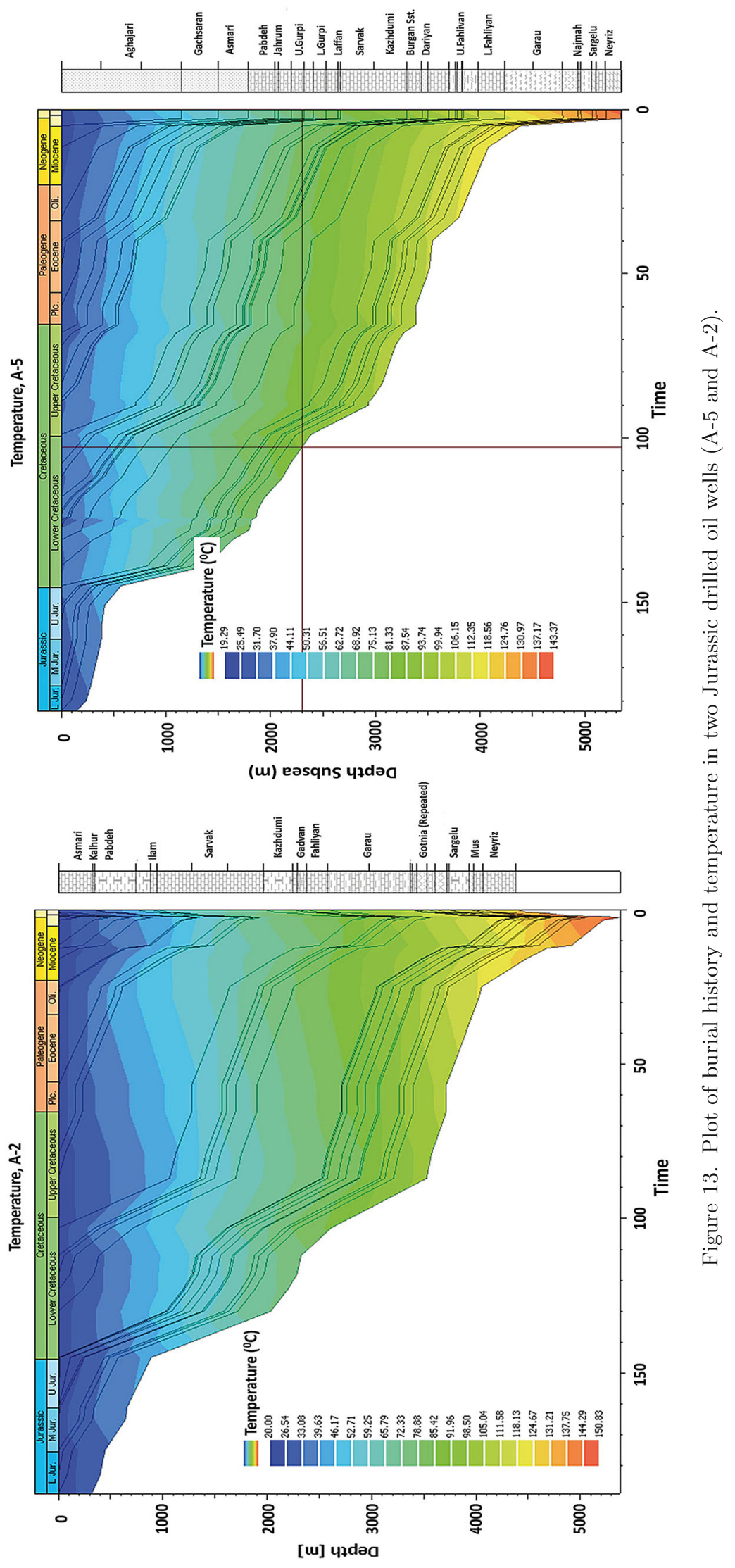



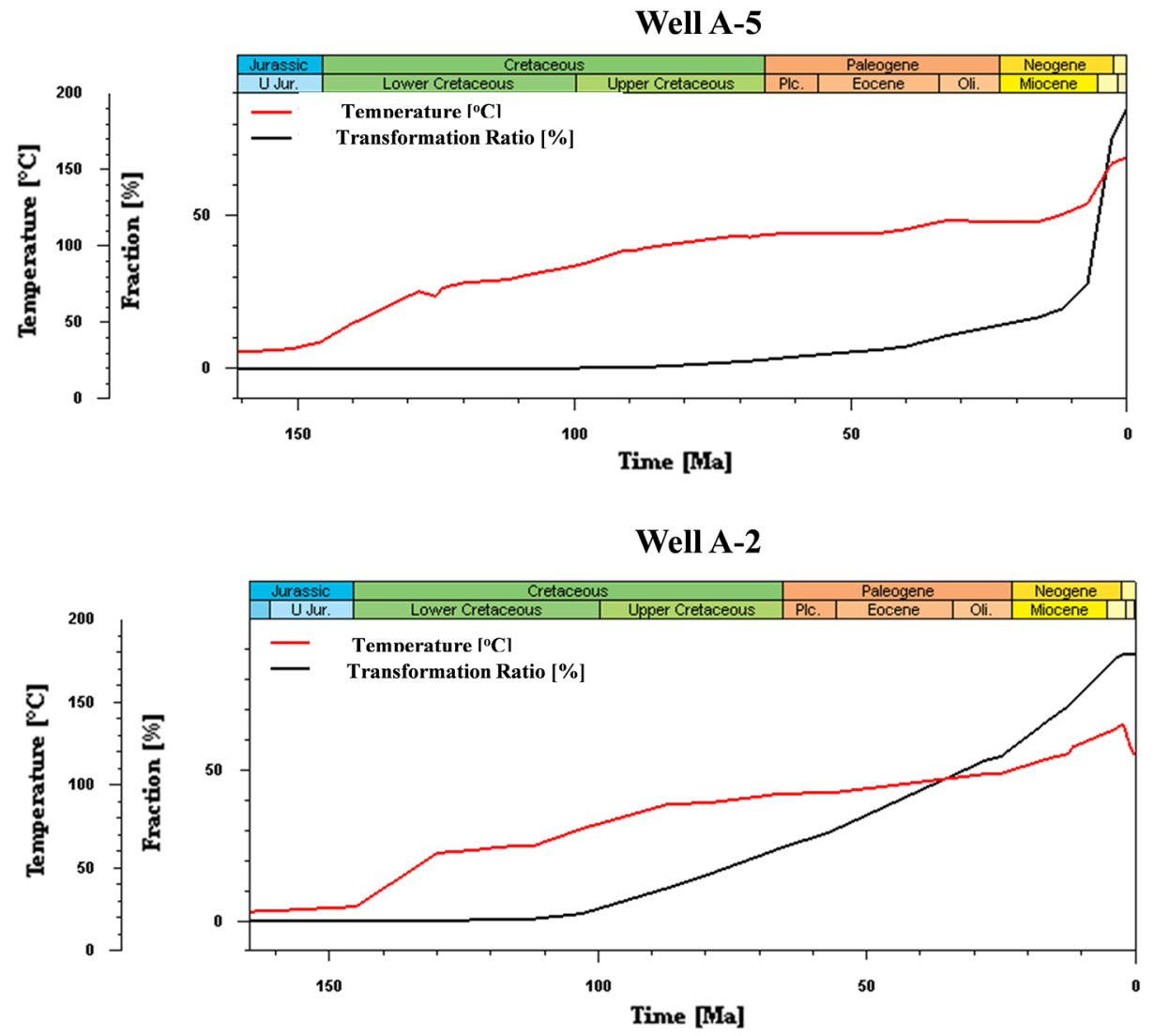

Figure 14. Plot of temperature and transformation ratio vs. time in the Jurassic Sargelu Formation in the wells A-5 and A-2.

is shown in the star diagrams of figure 11, there is very good correlation among all the studied oil samples (solid lines) in which they can be put in the same oil family. In addition the correlation between oil and source rock samples is acceptable which means condensates in the Jurassic reservoirs have been generated by the Jurassic Sargelu Formation.

\subsection{Modelling hydrocarbon generation}

Petroleum system modelling is a tool most often used to describe the modelling of the series of processes that include generation, expulsion, migration, trapping and preservation of the hydrocarbons within a specific system. Modelling of petroleum systems is a compromise between what one would like to do and what our limited knowledge permits. As a result, most workers in the field of system modelling are sceptical about the quantitative potential of such models and prefer to use them comparatively or semi-quantitatively at most (Barker 1996).

1D basin modelling was applied to describe the hydrocarbon generation in Jurassic petroleum system in two key wells in Zagros basin using PetroMod software.

Formation tops, ages and lithologies for drilled strata were taken from palaeolog which was prepared based on geological and palaeontological studies of the oil fields.

The Sargelu Formation was considered as a source rock in the modelling process. Initial geochemical properties of the Sargelu Formation have been used from a joint study between NIOC and BP (unpublished report 2001) and initial TOC and HI are $5-8 \%$ and $600-650 \mathrm{mg} / \mathrm{g}$ TOC, respectively.

Corrected bottom-hole temperatures were applied to define the present-day heat flow that was considered constant in the model to test the fit of calculated vitrinite reflectance against observed data from drilled wells. Plots of figure 12 show 
there is a good correlation between measured and calculated vitrinite reflectance and temperature.

In modelling of Asmari oil field which is located in Dezful embayment a $1000 \mathrm{~m}$ erosion was considered using near geological surface sections along with correlation to adjacent drilled wells. Heat flow as most important boundary condition factor for source rock maturity and hydrocarbon generation has been considered constant as $45-48 \mathrm{~mW} / \mathrm{m}^{2}$.

Plot of figure 13 shows the burial history and temperature evolution in the studied oil fields. The Jurassic Sargelu Formation has entered oil window in middle Cretaceous and the main expulsion (transformation ratio more than 25\%) from this formation occurred in the Miocene and Eocene time in the Abadan Plain and north of Dezful embayment, respectively. The highest temperature in this formation had been $145^{\circ} \mathrm{C}$. Transformation ratio in the Sargelu Formation reaches 90-100\% which means almost all PP has been generated (figure 14). Models show Jurassic strata in recent time are in condensate window which are in good correlation with reality of having condensate in the Drill Stem Test of drilled wells.

\section{Conclusions}

During this study, Jurassic petroleum system in the Zagros basin was characterised geochemically. The most important Jurassic source interval, the Sargelu Formation with average TOC value of $3.8 \%$ and initial $\mathrm{HI}$ value of $600 \mathrm{mg} \mathrm{HC} / \mathrm{g}$ TOC can be classified as a very good to excellent source rock. Kerogen type of this formation was considered to be type II. Rock-Eval pyrolysis and vitrinite reflectance measurements indicated that the maturity in the Sargelu Formation is in late oil to wet gas all over the studied area.

In the oil geochemistry study, four condensate and four source rock extract samples from three oil fields in the Zagros basin were analysed. Geochemical parameters such as CPI, $\mathrm{Pr} / n \mathrm{C}_{17}$ and $\mathrm{Ph} / n \mathrm{C}_{18}$ as well as maturity indicating biomarkers showed advanced level of maturity for the studied samples. $\mathrm{C}_{27}, \mathrm{C}_{28}$ and $\mathrm{C}_{29}$ steranes distribution as well as $\mathrm{DBT} / \mathrm{Phen}$ ratio and canonical variable showed marine carbonate and shale source environment for condensates. Lack of oleanane biomarker and isotopic values suggested early Mesozoic age for source of the studied samples.

Finally regarding all the GC and GC-MS parameters of the samples, there is a very good similarity among oil samples which put them in the same family. In addition, correlation between oil and source rock samples revealed that the entire Jurassic hydrocarbon is generated by Jurassic Sargelu Formation.

Thermal history reconstruction by PetroMod 1D basin modeller was carried out for two key wells which have penetrated the Jurassic succession. Initial TOC and $\mathrm{HI}$ values were considered to be $5-8 \%$ and $600 \mathrm{mg} \mathrm{HC} / \mathrm{g}$ TOC, respectively. Models showed that Sargelu Formation is in condensate window at present time and had entered oil generation window at middle Cretaceous. The maximum temperature reached for this formation has been $145^{\circ} \mathrm{C}$ and almost all its oil PP has been generated.

\section{Acknowledgements}

The authors would like to sincerely thank National Iranian oil company exploration directorate for providing samples, data and financial support of geochemical analysis. We are also grateful to geochemistry department of NIOCEXP especially Mr. Manuchehr Daryabandeh for helpful discussions and comments which improved the original paper.

\section{References}

Ala M A 1974 Salt diapirism in southern Iran; $A A P G$ Bull. 58(9) 1758-1770.

Alavi M 2007 Structures of the Zagros fold-thrust belt in Iran; Am. J. Sci. 307(9) 1064-1095.

Alizadeh B, Adabi M H and Tezheh F 2007 Oil-oil correlation of Asmari and Bangestan reservoirs using gas chromatography and stable isotopes in Marun oil field, SW Iran; Iran J. Sci. Technol. A 31(3) 241-253.

Alizadeh B, Sarafdokht H, Rajabi M, Opera A and Janbaz M 2012 Organic geochemistry and petrography of Kazhdumi (Albian-Cenomanian) and Pabdeh (Paleogene) potential source rocks in southern part of the Dezful Embayment, Iran; Org. Geochem. 49 36-46.

Alsharhan A S and Nairn A E M 2003 Sedimentary Basins and Petroleum Geology of the Middle East; Elsevier Science B.V., Amsterdam, Netherlands, 843p.

Barker C 1996 Thermal Modeling of Petroleum Generation: Theory and Applications; Elsevier, Amsterdam, 512p.

Berberian M and King G C P 1981 Towards a paleogeography and tectonic evolution of Iran; Can. J. Earth Sci. 18(2) 210-265.

Bjorøy M, Hall K, Hall P B and Leplat P 1992 Detailed hydrocarbon analyser for well site and laboratory use; Mar. Petrol. Geol. 9(6) 648-665.

Bordenave M L and Hegre J A 2010 Current distribution of oil and gas fields in the Zagros Fold Belt of Iran and 
contiguous offshore as the result of the petroleum systems; Geol. Soc. Lond. Spec. Publ. 330(1) 291-353.

Bordenave M L and Huc A Y 1995 The Cretaceous source rocks in the Zagros foothills of Iran: An example of a large size intra-cratonic basin; Rev. Inst. Français Pétrole $\mathbf{5 0}$ $527-753$.

Chung H M, Rooney M A, Toon M B and Claypool G E 1992 Carbon isotope composition of marine crude oils; Am. Assoc. Pet. Geol. Bull. 76 1000-1007.

Demaison G and Huizinga B J 1991 Genetic classification of petroleum systems (1); AAPG Bull. 75(10) 1626-1643.

Espitalié J, Laporte J L, Madec M, Marquis F, Leplat P, Paulet J and Boutefeu A 1977 Méthode rapide de caractérisation des roches mètres, de leur potentiel pétrolier et de leur degré d'évolution; Rev. Inst. Français Pétrole 32(1) 23-42.

Falcon N L 1967 The geology of the north-east margin of the Arabian basement shield; Adv. Sci. 24 31-42.

Hunt J M 1996 Petroleum Geochemistry and Geology; Vol. 2, WH Freeman, New York, pp. 1-743.

Jassim S Z and Goff J C (eds) 2006 Geology of Iraq; Dolin, Brno, distributed by Geol Soc. London, pp. 232250.

Moldowan J M, Seifert W K and Gallegos E J 1985 Relationship between petroleum composition and depositional environment of petroleum source rocks; $A A P G$ Bull. 69(8) 1255-1268.

Motiei H 1995 Petroleum geology of Zagros; Publication of the Geological Survey of Iran, Iran, 589p (in Persian).

Muris R J 1980 Middle East stratigraphic evolution and oil habitat; AAPG Bull. 64 597-618.

National Iranian Oil Company exploration directorate 2010 Zagros Structure Map, unpublished.

Peters K E and Cassa M R 1994 Applied source rock geochemistry; In: The petroleum system - From source to trap (eds) Magoon L B and Dow W G, AAPG Memoir 60 93-120.

Peters K and Moldowan J M 1993 The Biomarker Guide. Interpreting Molecular Fossils in Petroleum and Ancient Sediments; Prentice Hall, New Jersey.

Peters K E, Clutson M J and Robertson G 1999 Mixed marine and lacustrine input to an oil-cemented sandstone breccia from Brora, Scotland; Org. Geochem. 30(4) 237248.

Pitman J K, Steinshouer D and Lewan M D 2004 Petroleum generation and migration in the Mesopotamian Basin and Zagros Fold Belt of Iraq: Results from a basin-modeling study; GeoArabia 9(4) 41-72.

Rabbani A R and Kamali M R 2005 Source rock evaluation and petroleum geochemistry; Offshore $S W$ Iran J. P. G. 28(4) 413-428.

Radke M and Welte D 1983 The methylphenanthrene index (MPI): A maturity parameter based on aromatic hydrocarbons; Adv. Org. Geochem. 1981 504-512.

Sadooni F N 1997 Stratigraphy and petroleum prospects of Upper Jurassic carbonates in Iraq; Petrol. Geosci. 3(3) 233-243.

Sepehr M and Cosgrove J W 2004 Structural framework of the Zagros fold-thrust belt, Iran; Mar. Pet. Geol. 21(7) 829-843.

Setudehnia A 1978 The Mesozoic sequence in southwest Iran and adjacent area; JPG 1(1) 3-42.

Sherkati S and Letouzey J 2004 Variation of structural style and basin evolution in the central Zagros (Izeh zone and Dezful Embayment), Iran; Mar. Pet. Geol. 21(5) 535-554.

Sofer Z 1984 Stable carbon isotope compositions of crude oils: Application to source depositional environments and petroleum alteration; AAPG Bull. 68(1) 31-49.

Stocklin J 1968 Structural history and tectonics of Iran: A review; AAPG Bull. 52(7)1229-1258.

Stöcklin J 1974 Possible ancient continental margins in Iran; In: The Geology of Continental Margins, Springer, Berlin, Vol. 688, pp. 873-887.

Taylor G H, Teichmüller M, Davis A, Diessel C F K, Littke R and Robert P 1998 Organic Petrology; Gebrüder Borntraeger, Berlin, Stuttgart.

Tissot B P and Welte D H 1978 Petroleum Formation and Occurrence: A New Approach to Oil and Gas Exploration; Springer Verlag, New York, pp. 50-70.

Zeinalzadeh A, Moussavi-Harami R, Mahboubi A and Sajjadian V A 2015 Basin and petroleum system modeling of the Cretaceous and Jurassic source rock of the gas and oil reservoirs in Darquain field, south west Iran; J. Nat. Gas. Sci. Eng. 26 419-426. 